\title{
A Case Study of Why it is Important to Provide Financial Counselling for Vulnerable Students at University.
}

\author{
Robyn Angus \\ Financial Counsellor \\ La Trobe University Student Union.
}

\begin{abstract}
The La Trobe University Student Union (LTSU) is the peak representative body for La Trobe University students at the Melbourne, Mildura and Shepparton campuses LTSU has a specific focus on students who are vulnerable, in terms of experiencing financial stress. LTSU aims to assist these students by providing free student advocacy, legal and financial counselling services. Following are some of the typical issues faced by students at La Trobe University who seek financial counselling, the type of assistance provided, the positive outcomes and some practical guidance for others to replicate.
\end{abstract}

\section{What is financial counselling?}

Financial Counsellors are professionals who provide assistance, advocacy and information to those who are experiencing financial difficulty. The professional code of ethics requires that the service is provided without charging clients, that client confidentiality is maintained, and independence and absence of conflicts is ensured (Financial and Consumer Rights Council, FCRC, 2018).

Financial Counsellors (FCs) advocate for clients in debt with creditor organisations, and can do so under a specific credit licence exemption from Australian Securities and Insurance Commission (ASIC). The licence exemption is granted, subject to FCs being professionally qualified and eligible to be members of the relevant state body (in Victoria, FCRC), being employed by a non-profit organisation and not charging a commission or fee for service.

\section{Financial Counselling Services on campus}

Financial Counsellors provide counselling casework sessions to eligible clients. At La Trobe University, all enrolled students are entitled to this free service, and those who are experiencing financial difficulty may seek assistance. In addition, emergency relief services are available for immediate assistance in crisis situations. Referral pathways to off-campus services are also coordinated, to Centrelink or other external housing and health providers.

\section{Financial capability workshops}

Financial capability training workshops are also conducted. This educative approach is partnered with casework to prevent future difficulties for students. These workshops focus on budgeting, saving, avoiding debt traps and understanding superannuation.

\section{Coordinated services}

Financial Counselling is another dimension of the wider provision of student support services on campus. Student services include personal counselling and advocacy, to assist students manage their difficulties and succeed with their study. Often these services can be coordinated for students with multiple difficulties. It is important that all this support is located on campus, as many students would not be aware of off-campus community services, or have time to attend those appointments.

\section{Outcomes}

As the student survey data described below indicate, student outcomes from the first two years of a Financial Counselling practice at La Trobe University demonstrate the importance of this service as 
an essential student service, providing relevant assistance to students who may face temporary unemployment or accommodation crisis, or other students who have long-term needs and no parental support. Offering assistance at these crucial times, offers encouragement and increases the likelihood of successful completion of their degree.

\section{What are the issues faced by financial counselling clients at La Trobe University?}

In their recent comprehensive study of financial stress and financial resilience in Australia, Marjolin, Muir, Ramai, \& Powell (2017) found that 'those in short-term rentals, younger than 35 years old, from non-English speaking background, and those with mental illness, are prone to financial stress' (p. 9). This description is a good fit for many tertiary students, who are particularly vulnerable to financial stress. As Newton's (2000) study of students at Ballarat University puts it, 'Poor students saw their well-being and self-worth affected by poverty as they struggled to escape a cycle of indebtedness and risked academic standards by working longer hours' (p.251)

\section{Student issues 2017}

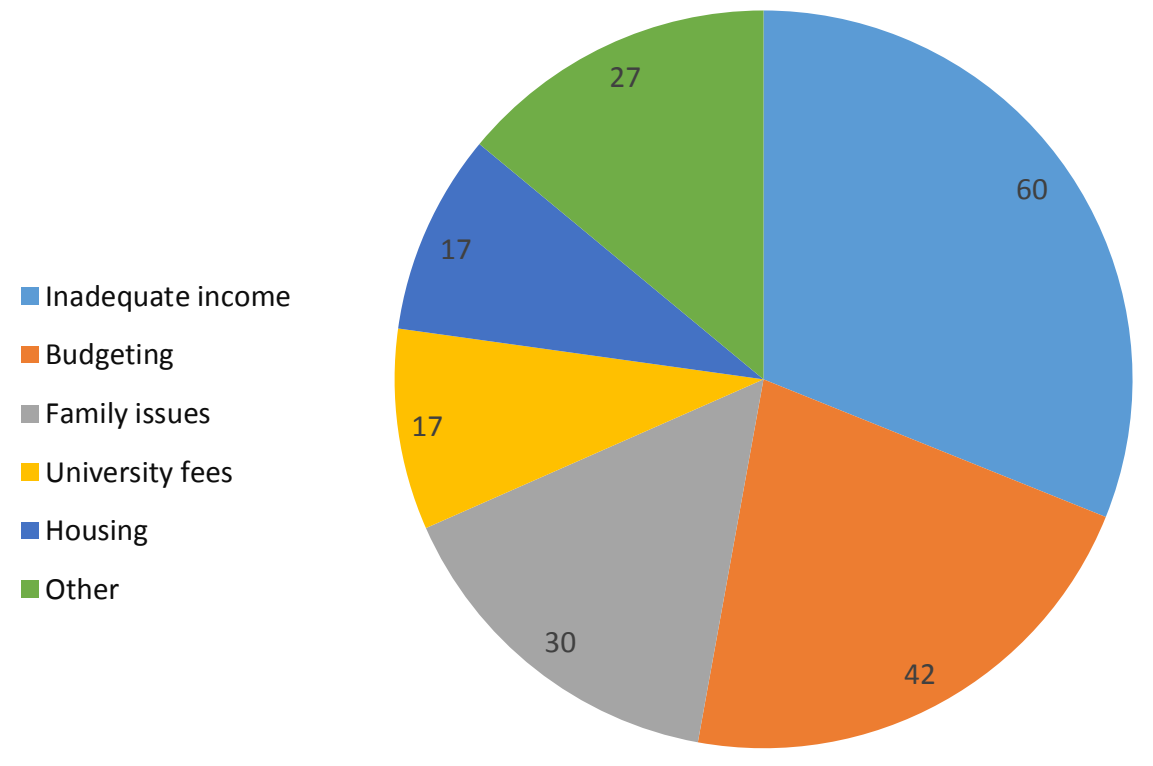

Figure1: Student issues 2017

Figure 1 above, derived from LTSU student data (LTSU, 2017), illustrates the issues faced by the students who attended financial counselling sessions in 2017 at La Trobe University. This survey data show that most clients faced several of these issues, in addition to health and academic disadvantage. At La Trobe University, the financial counselling clients are often first in their family to come to university, with parents who are dependent on Centrelink benefits, are short-term renters, working part-time to cover expenses, and with low financial literacy skills. Clients also have high levels of financial exclusion, as measured by access to financial products (Muir, Marjolin \& Adams, 2015). Many student clients did not possess a credit card, could not raise $\$ 2000$ for an expense, and many also owed money to family and friends (LTSU, 2017).

\section{Impact of Financial Counselling Services at LTSU}

\section{Emergency Relief}

Financial counselling provides material relief for those who need food, a transport ticket, phone recharge, or a shopping voucher. LTSU is also registered with the Women's Services Network 
(WESNET) as an agency for assisting victims of family violence and provides referral to other professional domestic-violence resources.

At La Trobe University in 2017, the Financial Counsellor assisted 95 students who were facing either immediate risk of homelessness, or insufficient income for travel, mobile phone re-charge or food for the week (Figure.2).

\section{LTSU \\ Emergency Aid 2017}

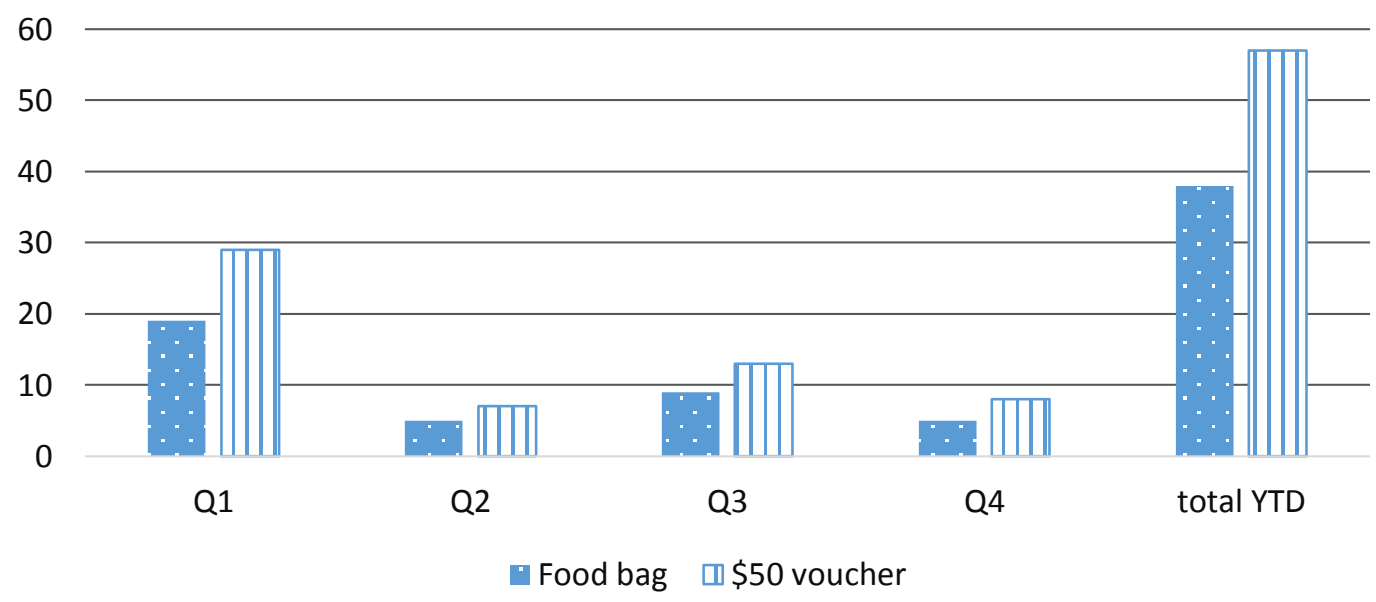

Figure 2: Emergency aid 2017

The LTSU data reveal that $40 \%$ of clients are surviving solely on Youth Allowance benefits, which provide less than $\$ 15,000$ per annum (LTSU, 2017). A large proportion of student clients (40\%) are renters, and rental costs typically accounted for $62 \%$ of income. As a reference point, housing costs in excess of $30 \%$ of income are regarded as the level at which a client will experience financial stress (Marjolin et al., 2017). Eighteen students could not pay their housing costs and were at risk of homelessness, and six were actually homeless.

LTSU offers short-term resources and can also refer to the wider Financial Counselling community for further help off-campus. Emergency relief helps students in financial difficulty to manage in the short-term, but the more systemic issues of long-term debt and rent assistance require dedicated ongoing casework. The implications for student retention is worthy of further research.

\section{Financial Counselling casework}

Over the six months July to December 2017, a client casework questionnaire identified the following outcomes. The questionnaire surveyed 42 students. Only four students who sought help had to leave University due to financial issues; 38 (90\%) were able to continue study and manage their issues, as illustrated below in Figure 3. 


\begin{tabular}{lc}
\hline $\begin{array}{l}\text { Financial Counselling Client } \\
\text { outcomes July - Dec 2017 }\end{array}$ & \% of Clients \\
\hline $\begin{array}{l}\text { Benefited from changing } \\
\text { income/expenses }\end{array}$ & $19 \%$ \\
$\begin{array}{l}\text { Gained funding: grant, fee } \\
\text { relief }\end{array}$ & $21 \%$ \\
Emergency Relief provided & $19 \%$ \\
$\begin{array}{l}\text { Hardship: waiver or payment } \\
\text { plan }\end{array}$ & $24 \%$ \\
Left University or unknown & $10 \%$ \\
On-going clients - no outcome & $7 \%$ \\
\hline
\end{tabular}

Client outcomes

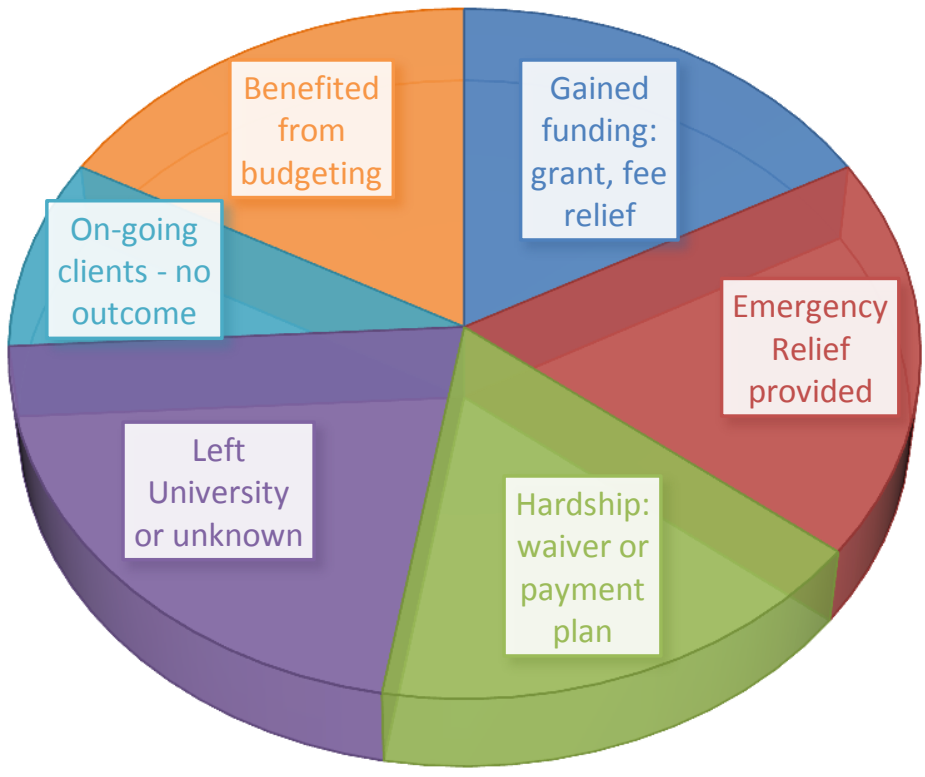

Figure 3: La Trobe student outcomes - 2017

Some students were assisted in claiming Centrelink benefits that they were eligible for; they had either not realised their eligibility, or were having difficulty proving eligibility. Other students gained assistance with repayment plans for their University fees, or for applying for scholarships and grants from the university.

Some students were assisted with accessing hardship arrangements in relation to debts, making arrangements for waivers or payment plans. Referrals were made to the campus lawyer to assist with legal issues with tenancy or with unscrupulous employer practices. For example, one student was financially crippled by large repayments to a credit card, but after discussion with the bank, repayments were reduced, interest charges waived and fees removed. Assisting students to acknowledge their financial issues and to manage them early, can enable these students to continue their studies more successfully. This is particularly so when students participate in financial literacy training; the new skills and knowledge they gain enable them to prevent financial problems repeating in the future. 


\section{Financial capability training}

The students who attend financial counselling, although academically able, may not always have good financial literacy skills or knowledge. When faced for the first time with financial decisions, such as mobile phone contracts, rental leases or credit cards, problems can result.

At La Trobe University, it was also found that the financial capability training for students in need is a necessary partner of casework practice. This is consistent with evidence from Gerrans and Heaney (2014) who identified the positive effects of developing the financial skills of tertiary students. Students are particularly receptive of any help with managing their financial resources and improving their skills to manage their limited income. As a result of the financial capability workshops conducted over 2016 and 2017, the student feedback is unanimously in support of this learning opportunity. The advantages of an educative, client-based approach is illustrated below in Figure 4.

Karen* is a recently widowed mother of two, originally from Lebanon, studying Arts, but struggling with the loss of her husband, and the financial implications of widowhood.

Initially through attendance at the financial capability workshop, Karen improved her knowledge of the financial system and the mechanisms of banking and lending in Australia. The workshop improved Karen's skills in applying this information to her own situation.

Through on-going financial counselling sessions, Karen's knowledge and skills, with support from the financial counsellor, were applied to advocate to the bank, claim insurance and apply for family benefits and relief from some study expenses. Karen then gained a scholarship to study overseas and complete her studies

* Pseudonym used to maintain student confidentiality.

Figure 4. Case study - Karen

\section{Some recommendations about financial counselling on campus}

\section{Offer face-to-face, individual, professional financial counselling on campus.}

The provision of individual, free and professional financial counselling gives confidential and specific guidance and options for students struggling with their finances. Outcomes measured so far at $\mathrm{La}$ Trobe University point to positive changes in behaviour, assisting students to self-manage future problems and sustain them through student life. On-campus provision is essential to enable access to the service.

\section{Students do benefit from financial capability training:}

Casework should be complemented by group financial capability workshops to improve financial literacy. This is especially relevant in an educational institution where students are already receptive and capable of learning.

Students are very responsive to learning financial skills, across disciplines. It cannot be overstated how important it is to provide opportunities for students, especially those from vulnerable backgrounds, to receive a good grounding in the Australian financial system.

\section{Systemic student financial issues identified}

Through working with students across emergency relief, casework and financial capability workshops, systemic financial issues can be identified, and further outreach and education can be planned, in order to have wider impacts and promote relevant services to students. This knowledge can also be fed into wider Financial Counselling networks and industry interactions to improve the 
operation of supports for students. For example, this can take the form of more accessible and better structured hardship programs, or better targeted outreach to students from Ombudsman schemes.

\section{Vulnerable student groups can be assisted, who are otherwise at risk of withdrawing because of financial pressures.}

Emergency relief is important to deal with immediate situations of homelessness, unemployment or personal emergencies. The provision of food parcels, vouchers, travel tickets and phone re-charge cards is essential for students in immediate and urgent need to cover travel expenses to campus, stay connected on-line for learning materials, purchase books and continue studying. However, this needs to be accompanied by longer-term casework to tackle the underlying issues. Without tackling both the immediate and underlying problems, the student is at greater risk of withdrawing from study.

Students are also vulnerable to inappropriate or unethical services being offered, such as additional credit, debt management or consolidation services. Financial counsellors can protect students from unethical providers and can often solve an issue without paying any fees or worsening the debt.

\section{Potential for financial counselling on other campuses}

The LTSU experience demonstrates the important benefits to students and tertiary institutions of the provision of financial counselling services. Such services can educate and assist students in areas of vulnerability, remove major barriers to academic progress, and support student retention. 


\section{References}

Bhansali, C. P. (2016). How to Make Learning Easier than Cheating. Retrieved from Edsurge: https://www.edsurge.com/news/2016-07-23-how-to-make-learning-easier-than-cheating

Desouza, K. C., \& Smith, K. L. (2016, August). Predictive Analytics: Nudging, Shoving, and Smacking Behaviours in Higher Education. Why IT matters to Higher Education: Educause Review, 1-11.

Dicheva, D., Dichev, C., Agre, G., \& Angelova, G. (2015, July). Gamification in Education: A Systematic Mapping Study. Journal of Educational Technology \& Society, 18, 75-88.

Fielding, M. (2004). Transformative approaches to student voice: theoretical underpinnings, recalcitrant realities. British Educational Research Journal, 295-311.

Gee, J. (2008). The ecology of games: Connecting youth, games and learning. Cambridge : The MIT Press.

Huang, W. H.-Y., \& Soman, D. (2013). A practitioner's Guide to Gamification of Education. Toronto: Rotman School of Management.

Klopfer, E., Osterweil, S., \& Salen, K. (2009, Aug 21). Moving learning games forward. Retrieved from MIT: http://education.mit.edu/papers/MovingLearningGamesForward_EdArcade.pdf

Krause, K., \& Coates, H. (2008). Students' engagement in first-year university. Assessment and Evaluation in Higher Education, 493-505.

L., Z., \& Grabowski, B. (2004, October). The Effects of Various Animation Strategies in Facilitating the Achievement of Students on Tests Measuring Different Educational Objectives. Chicago: ERIC.

Lee, J. J., \& Hammer, J. (2011). Gamification in Education: What, How, Why Bother? Academic Exchange Quarterly, 15-19.

Li, C., Dong, Z., Untch, R., \& Chasteen, M. (2013). Engaging Computer Science Students through Gamification in an Online Social Network Based Collaborative Learning Evironment. International Journal of Information and Education Technology, 72-75.

Lizzio, A. (2006). Designing an Orientation and transition strategy for commencing students. Queensland: Griffith University.

MacMillian. (2011, January 19). Gamification: A growing business to invigorate stale websites. Retrieved from Business Week: http://www.businessweek.com/magazine/content/11_05/b4213035403146.htm

Marjolin, A., Muir, K., Ramai, I., \& Powell, A. (2017). Why is financial stress increasing? Financial Resilience in Australia 2016 -Part 1. Sydney: Centre for Social Impact, UNSW.

McGonigal, J. (2011). Reality is Broken: Why games make us better and how they can change the world. New York, NY: Penguin Press.

Muir, K., Marjolin, A., \& Adams, S. (2015). Eitht years on the fringe: what has it meant to be severely of fully financially excluded in Australia? Sydney: Centre for Social Impact for the National Australia Bank.

Newton, J., \& Turale, S. (2000). Student poverty at The University Of Ballarat. Australian Journal of Social Issues, issue 35, 35: 251-265.

Robinson, C., \& Hullinger, H. (2010). New benchmarks in Higher Education: Student Engagement in Online Learning. Journal of Education for Business, 101-109.

Robinson, C., \& Taylor, C. (2007). Theorizing student voice: values \& perspectives. Improving Schools, 10, 5-17.

Salen, K., \& Zimmerman, E. (2003). Rules of Play: Game design fundamentals. Cambridge: MIT Press.

Singh, O. K., \& O'Donoghue, J. (2004). Implementing e-Learning Programmes for Higher Education. Journal of Information Technology Education, 3, 314-323.

Student Union, La Trobe University . (2017). LTSU Survey Data. Melbourne, Victoria, Australia.

Wankel, L. A. (2013). Increasing Student Engagment and Retention using mobile applications. New York: Emerald Group Publishing.

Zichermann, G., \& Cunningham, C. (2011). Gamification by Design: Implementing Game Mechanics in Web and Mobile Apps. Cambridge: O'Reilly. 
The author may be contacted:

R.Angus@latrobe.edu.au

\section{Please cite this paper as:}

Angus, R. (2018). A case study of why it is important to provide Financial Counselling for vulnerable students at University. Journal of the Australian and New Zealand Student Services Association, 26(2), 113-120. https://doi.org.10.30688/janzssa.2018.08 